\title{
The Effects of Oxygen on the Possible Repair of Dehydration Damage by Escherichia coli
}

\author{
By S. J. WEBB \\ Department of Bacteriology, University of Saskatchewan, \\ Saskatoon, Saskatchewan, Canada
}

(Accepted for publication I July 1969)

\begin{abstract}
SUMMARY
Proflavine in the post-aerosolization plating medium lowered by over $80 \%$ the number of viable Escherichia coli $\mathbf{B} / \mathbf{R}$ organisms recovered from aerosols of $55 \%$ relative humidity (RH) and above, but had no effect on the recovery of viable $E$. coli $\mathrm{WP}_{2}$ organisms. Oxygen enhanced the lethal action of semi-dehydration on $E$. coli strain $\mathrm{B} / \mathrm{R}$, held at $50 \% \mathrm{RH}$ and below, but had less effect on the survival of $E$. coli $\mathrm{WP}_{\mathrm{s}}$. In addition, $E$. coli $\mathrm{B} / \mathrm{R}$ organisms displayed an increased rate of respiration, and discharged $260 \mathrm{~m} \mu$ absorbing material, when held at intermediate values of RH. These phenomena were not observed with $E$. coli WP2 ${ }_{\mathrm{s}}$ organisms. Thus $E$. coli $\mathrm{B} / \mathrm{R}$ seems to possess an energy consuming mechanism by which it is able to survive semi-dehydration above $55 \% \mathrm{RH}$ by a discharge of damaged cell components. This mechanism is very slowly destroyed when the organisms are semi-dehydrated in nitrogen but, below $50 \% \mathrm{RH}$, it is rapidly inactivated by oxygen. It is suggested that the mechanism is a membrane-bound system, possibly involving the cytochrome chain.
\end{abstract}

\section{INTRODUCTION}

When bacteria are held in an aerosolized state for prolonged periods, the rate at which they lose viability depends on the quantity of water vapour and oxygen present in their gaseous environment and on the environmental temperature. Much of the relevant work done between 1920 and 1953 has been summarized by Wells (I955) and by Webb (1965). From these investigations it was concluded that one of the main factors which determines the rate of loss of viability is the partial pressure of water vapour. Between 10 and $40^{\circ}$ the partial vapour pressure and temperature, usually expressed as a relative humidity $(\mathrm{RH})$, controls the rate at which organisms die, rather than the absolute water content of the air (Wells, I955), apparently because the RH determines the quantity of water bound to macromolecules within the cell (Webb, 1960). Most investigators have found organisms held at $25^{\circ}$ and at relative humidities above $75 \%$ to be stable. In contrast, however, Cox $(1967,1968)$ found that Escherichia coli died rapidly when held in an atmosphere of nitrogen at relative humidities between 85 and $75 \%$.

Oxygen appears to enhance the rate at which organisms die only when they are held at $\mathrm{RH}$ values below $40 \%$ (Webb, 1965, 1967; Hess, 1965), suggesting that the presence of water prevents the oxidation of cell constituents. The mechanism by which they are killed at relative humidities between 80 and $40 \%$, therefore, appears to differ from that responsible for their death at $40 \% \mathrm{RH}$ and below. Results are described here 
which indicate that the respiratory mechanisms of bacteria are damaged by oxygen when they are held below $40 \% \mathrm{RH}$ but that, at higher $\mathrm{RH}$ values, death appears to be due, in part, to the destruction of a mechanism by which some strains are able to repair the dehydration damage which otherwise would impair their ability to manufacture protein and nucleic acid.

\section{METHODS}

Organisms. (a) Escherichia coli B/R (NCIB 9485), a strain resistant to ultraviolet radiation (u.v.) due to its ability to dark repair DNA damage, and (b) Escherichia coli WP2 $_{\mathrm{B}}$, a tryphtophan requiring mutant of $E$. coli $\mathbf{B} / \mathbf{R}$, which is unable to perform host cell reactivation of bacteriophage, is highly sensitive to $u . v$. and has a reduced ability to dark repair u.v. damage (Hill, I965; Ashwood-Smith \& Bridges, 1966).

Preparation of aerosols in air. Escherichia coli, strains $\mathbf{B} / \mathbf{R}$ and $\mathrm{WP}_{\mathrm{s}}$, were grown for $24 \mathrm{hr}$ at $37^{\circ}$ in Bacto Nutrient Broth (NB), harvested and washed twice in de-ionized distilled water and resuspended in either $(a)$ distilled water or $(b) 0.3 \mathrm{M}$-raffinose or 0.3 M-myo-inositol to a concentration of $\mathrm{I} \times \mathrm{IO}^{10}$ bacteria $/ \mathrm{ml}$. These organisms were then aerosolized for $5 \mathrm{~min}$. into a $800 \mathrm{l}$. stainless steel rotating drum by using a Collison spray operating at 25 p.s.i. The air was supplied from a carbon ring compressor and, before use, was passed through two bacterial filters (to remove fine particles) and two columns each of activated charcoal and silica gel. The $\mathrm{RH}$ value was pre-set by spraying distilled water into the drum until a given RH value had been obtained. Samples were collected from the aerosol by using a liquid impinger containing $9 \mathrm{ml}$. $0.5 \mathrm{M}$-glucose in $0.85 \%(\mathrm{w} / \mathrm{v}) \mathrm{NaCl}$. Serial ten-fold dilutions then were made in nutrient broth and $0.2 \mathrm{ml}$. of each dilution plated onto nutrient agar and nutrient agar containing $5 \mu \mathrm{g}$. proflavine $/ \mathrm{ml}$. To the remainder of the initial sample $\mathrm{I} \mathrm{ml} .0 \cdot \mathrm{I} \%(\mathrm{w} / \mathrm{v})$ casamino acids in potassium phosphate buffer ( $\mathrm{pH} 6 \cdot 9$ ) was added and immediately a $2 \mathrm{ml}$. sample withdrawn. The rest was placed in an incubator at $37^{\circ}$ and allowed to incubate for $45 \mathrm{~min}$. The $2 \mathrm{ml}$. portion originally removed was passed through a Millipore filter to remove bacteria, and the same treatment was given to the incubated bacteria following the $45 \mathrm{~min}$. incubation period. The difference between extinction at $260 \mathrm{~m} \mu$. of filtrates from the initial and the incubated samples was determined with a Beckman DB spectrophotometer.

One of the difficulties in the estimation of the respiration rate of bacteria after periods of storage in air is the rapid loss of viability encountered at low $\mathrm{RH}$ values. To overcome this problem the storage time in aerosols was decreased to $5 \mathrm{~min}$., samples were taken as above and the organisms in each sample concentrated in O.I M-phosphate buffer, to $5 \times 10^{8}$ bacteria/ml., by centrifugation. The bacterial concentration was standardized with a Coleman nephelometer and, therefore, the bacterial count at the time the $\mathrm{O}_{2}$ uptake measurements were made was a total count, not a viable one. Viable counts were made by serial dilution, plating on nutrient agar and counting the colonies after $24 \mathrm{hr}$ of incubation. After the bacteria had been concentrated, $2 \mathrm{ml}$. portions were placed in the main chamber of a Bronwell Warburg flask and $0.5 \mathrm{ml}$. of a solution of $0.1 \mathrm{M}$-glucose $+500 \mu \mathrm{g}$. casamino acids $/ \mathrm{ml}$. placed in the side arm. Oxygen uptake was measured at $37^{\circ}$ with double capillary manometers.

Preparation of aerosols in nitrogen. The bacterial suspensions were prepared as above, but using deaerated (boiled) distilled water. The suspension was then placed into a Collison spray and nitrogen gently bubbled through it for about $60 \mathrm{~min}$. For 
use in the aerosol studies the nitrogen was washed successively with (a) alkaline pyrogallol, (b) water, $(c) \mathrm{N}-\mathrm{H}_{2} \mathrm{SO}_{4},(d) \mathrm{N}-\mathrm{NaOH},(e)$ water, and then passed through the silica driers and charcoal columns to the aerosol drum. The drum was purged with the cleaned nitrogen for $2 \mathrm{hr}$ and then a Collison spray, containing water free from dissolved oxygen, was introduced into the system. The spray was operated with nitrogen until a given $\mathrm{RH}$ value was reached and then replaced by the spray containing the bacterial suspension which was 'atomized' into the drum for $5 \mathrm{~min}$. All other procedures were as above. The reasons for the extensive washing of the nitrogen will be evident from the text.

Measurement of release of thymidine-2- ${ }^{14} \mathrm{C}$. Bacteria of both strains were grown at $37^{\circ}$ for $24 \mathrm{hr}$ in a medium consisting of: $0 . \mathrm{I} \mathrm{M}$-glucose, $500 \mu \mathrm{g}$. casamino acids $/ \mathrm{ml}$. and $0.8 \mu \mathrm{c}$. $\left[{ }^{14} \mathrm{C}\right]$ thymidine $(34 \mathrm{mc}$. $/ \mathrm{m}$-mole)/ml. all in $0 . \mathrm{I}$ M-phosphate buffer ( $\mathrm{pH} \mathrm{6.9})$. The $\left[{ }^{14} \mathrm{C}\right]$-labelled thymidine was purchased from New England Nuclear Corp., Boston, Mass., U.S.A. The bacteria were harvested, washed, aerosolized and collected as above. After $15 \mathrm{~min}$. of storage, triplicate $10 \mathrm{ml}$. samples were taken and casamino acids (to $500 \mu \mathrm{g}$. $/ \mathrm{ml}$.) and, in some cases, proflavine (to $5 \mu \mathrm{g} . / \mathrm{ml}$.) added to each. The samples were incubated for $45 \mathrm{~min}$. at $37^{\circ}$ and the bacteria removed by passage through Millipore filters of $0.45 \mu$ porosity. Each filtrate was evaporated to dryness in vacuo, resuspended in $0.5 \mathrm{ml}$. of distilled water and placed into a $\mathrm{I}$ in. $(2.54 \mathrm{~cm}$.) stainless steel planchette containing a 0.75 in. $(1 \cdot 9 \mathrm{~cm}$.) diameter filter paper disc previously glued to the bottom of the planchette. The samples were then dried under an infrared lamp and the radioactivity present determined with a Phillips Gas Flow Counter.

\section{RESULTS}

\section{Effects of oxygen and relative humidity}

The two strains of Escherichia coli responded differently to changes in the RH value of the atmosphere in which the organisms were held. $E$. coli $\mathbf{B} / \mathrm{R}$, both in nitrogen and in air, was considerably more stable than the WP2 ${ }_{s}$ strain, especially at relative humidities above $40 \%$ (Fig. I). In addition, the ratio between the percentage recoveries of strains $B / R$ and $W P 2_{s}$ after $15 \mathrm{~min}$. in air or nitrogen showed that the difference in stability of the two strains was greatest when the bacteria were held at intermediate humidity values (Fig. I c). Oxygen affected the survival of strain $B / \mathbf{R}$ to a greater extent than it did that of strain WP2 $\mathrm{s}$. However, oxygen enhanced the death rate only at relative humidities below $50 \%$ (Fig. I).

\section{Effect of proflavine}

Webb \& Tai (1968) showed that the ability of airborne organisms to repair u.v.induced damage was gradually destroyed when they were held at RH values below $55 \%$. Since the two strains of Escherichia coli used vary in their ability to repair damage induced by u.v. radiation, it seemed possible that the added resistance of strain $\mathrm{B} / \mathrm{R}$ to dehydration at $\mathrm{RH}$ values above $50 \%$ might reside in an ability to repair comparable damage induced by semi-dehydration. Proflavine in the plating medium, as well as related acridine dyes and caffeine, apparently inhibit the repair system (Witkin, 1963; Lieb, 1964). Following aerosolization between 55 and $75 \% \mathrm{RH}$ proflavine in the growth medium greatly diminished the recoverable number of colonyforming organisms of $E$. coli $\mathrm{B} / \mathrm{R}$; the recovery of $E$. coli WP2 $2_{\mathrm{s}}$ was not affected (Fig. 2). 
This decrease in the number of surviving bacteria of strain $B / R$, due to proflavine, occurred both when the bacteria were held in air or in nitrogen at $\mathrm{RH}$ values between 75 to $55 \%$. Holding them in air at $\mathrm{RH}$ values below $55 \%$, however, resulted in a rapid decrease in the action of proflavine (Fig. $2 c, d$ ).
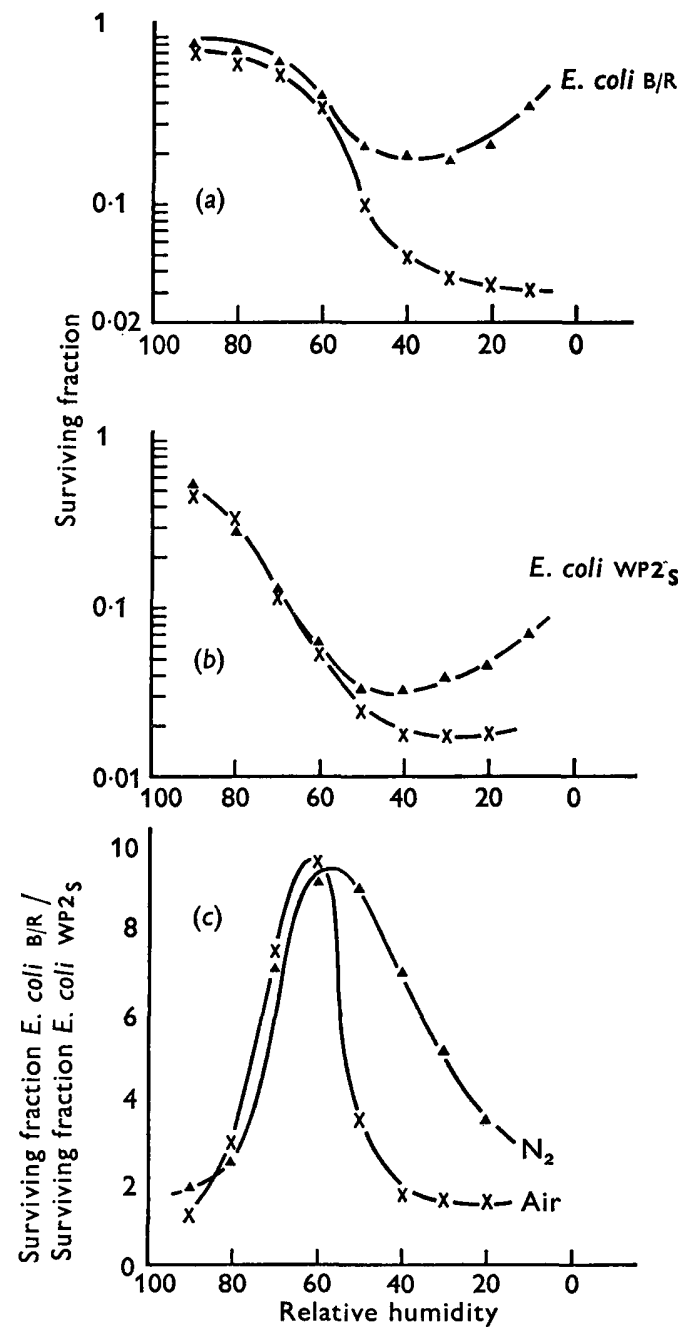

Fig. I. The effect of relative humidity and oxygen on the survival of airborne Escherichia coli strains $\mathrm{B} / \mathrm{R}$ and $\mathrm{WP}_{\mathrm{S}}$ after storage for $15 \mathrm{~min}$. (a) $E$. coli $\mathrm{B} / \mathrm{R}(\boldsymbol{\Delta})$ bacteria stored in $\mathrm{N}_{2},(\times)$ bacteria stored in air. (b) $E$. coli $\mathrm{WP2}_{\mathrm{S}}(\boldsymbol{\Delta})$ bacteria stored in $\mathrm{N}_{2},(\times)$ bacteria stored in air.

\section{Release of $260 \mathrm{m \mu}$-absorbing material and $\left[{ }^{14} \mathrm{C}\right]$ thymidine}

Since it was possible that the proflavine-sensitive function was similar to that by which the bacteria were able to repair u.v. damage, the presence of $260 \mathrm{~m} \mu$.-absorbing material in the filtrate of bacteria incubated after periods of storage was examined. Escherichia coli WP2, held at RH values between 90 and $10 \%$ and incubated for 45 
min. following aerosolization showed no significant increase in $260 \mathrm{~m} \mu$.-absorbing material in supernatant or filtrate fluids. However, an increase in u.v.-absorbing material in the filtrate fluids of strain $\mathbf{B} / \mathbf{R}$ was observed. This reached its maximum quantity after organisms had been stored at about $60 \%$ RH (Fig. 3), coinciding with both the relative sensitivities of the two strains used and the effect of proflavine in the plating medium; maximum differences between the two strains occurred when the bacteria were held at 55 to $60 \% \mathrm{RH}$.



Fig. 2. The effect of relative humidity and proflavine on the recovery of Escherichia coli STRAINS $B / R$ and WP2 from aerosols in $\mathrm{N}_{2}$ and air. $(a) E$. coli $\mathrm{B} / \mathrm{R}(\triangle)$ bacteria held in $\mathrm{N}_{2}$ plated on nutrient agar; $(\Delta)$ bacteria held in $\mathrm{N}_{2}$ plated on nutrient agar containing $5 \mu \mathrm{g}$. proflavine/ml.; $(x)$ bacteria held in air plated on nutrient agar; $(0)$ bacteria held in air plated on nutrient agar plus $5 \mu \mathrm{g}$. proflavine $/ \mathrm{ml}$.; (b) E. coli $\mathrm{WP}_{\mathrm{g}}(\Delta)$ bacteria held in $\mathrm{N}_{2}$ plated on nutrient agar; $(\triangle)$ bacteria held in $N_{2}$ plated on nutrient agar + proflavine; $(\Theta),(\times)$ bacteria held in air and plated on nutrient agar and nutrient agar + proflavine, respectively; $(c)$ $E$. coli WP2s; relative recovery = fraction surviving on nutrient agar/fraction surviving on nutrient agar plus proflavine; $(d) E$. coli $\mathrm{B} / \mathrm{R}$ relative recovery same as for $(c)$ above. $\mathrm{N}_{2}$ and air $=$ gas in which bacteria were held. Storage time, $15 \mathrm{~min}$.

In an attempt to ascertain whether the released u.v.-absorbing material was DNA, the radioactive counts/min. from a standard number of $\left[{ }^{14} \mathrm{C}\right]$ thymidine-labelled bacteria, before and after $45 \mathrm{~min}$. of incubation, was determined. This procedure failed to reveal DNA loss because the quantity of radioactive material released represented considerably less than $\mathrm{r} \%$ of the total cell DNA and the experimental error in radioactive counting was greater than $I \%$. The radioactivity found in the filtrates, however, simulated their $260 \mathrm{~m} \mu$. extinction value; the amount present in filtrates from Escherichia coli $\mathrm{B} / \mathrm{R}$ suspensions was greatest after storage at $60 \% \mathrm{RH}$ and decreased as the RH was decreased, especially when the organisms were held in air. 
A similar trend was found with strain $\mathrm{WP2}_{\mathrm{B}}$, but the quantity of released material was small. Proflavine decreased the radioactivity in filtrates of Escherichia coli $\mathrm{B} / \mathrm{R}$, but not that in $E$. coli WP2 $2_{\mathrm{s}}$ filtrates (Table I). It appeared, therefore, that the survival of $E$. coli $\mathrm{B} / \mathrm{R}$ at $\mathrm{RH}$ values above $60 \%$ depended on its ability to reject damaged material.
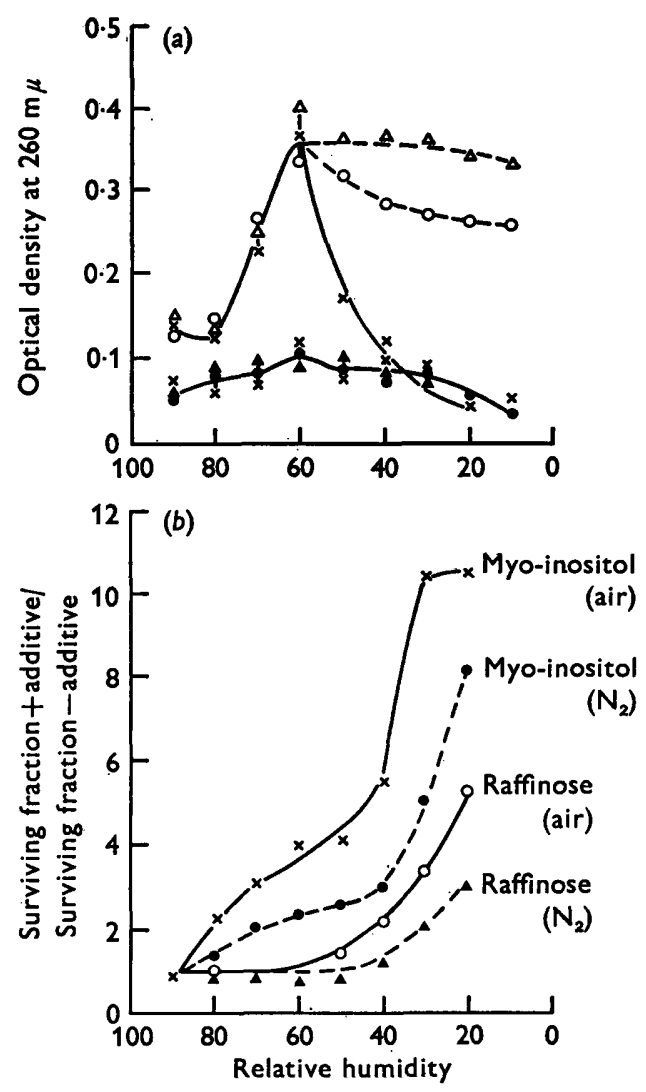

Fig. 3. The survival and release of $260 \mathrm{~m} \mu$.-absorbing material from Escherichia coli strains $B / R$ and WP2 after being held for $15 \mathrm{~min}$. in aerosols of various relative humidities with protective additives. (a) The release of $260 \mathrm{~m} \mu$.-absorbing material from bacteria held in air for $15 \mathrm{~min}$. $E$. coli $\mathrm{B} / \mathrm{R}$ aerosolized from a suspension in $0.3 \mathrm{M}$-myo-inositol $(\Delta), 0.3 \mathrm{M}$-raffinose (O), $\mathrm{H}_{2} \mathrm{O}(\times)$; E. coli WP2 $\mathrm{B}$ aerosolized from a suspension in $0.3 \mathrm{M}$-myo-inositol (A), 0.3 Mraffinose (O), $\mathrm{H}_{2} \mathrm{O}(\times)$; (b) ratio of the surviving fractions of $E$. coli $\mathrm{B} / \mathrm{R}$ obtained from aerosols in air and $\mathrm{N}_{2}$ in the presence of myo-inositol and raffinose.

\section{Effect of protective compounds}

To examine the above possibility, the ability of two compounds to preserve the mechanism by which damaged material was discharged from the organism was examined. Myo-inositol, a compound able to enter the cell, and raffinose, a compound unable to permeate through the cell membrane, were both able to preserve this mechanism at all relative humidities studied (Fig. 3). There was, however, a difference in the ability of these two compounds to preserve the viability of the organisms. Myoinositol afforded protection to bacteria held either in nitrogen or in air at all the RH values studied. Raffinose, on the other hand, offered little protection to organisms held 
at high RH value, but displayed a high protective ability at the low RH values (Fig. $3 b$ ). This particular finding with raffinose agrees with the observations of Cox (I968). Raffinose afforded Escherichia coli strain WP2 protection at low relative humidities when they were held in either air or nitrogen and the protection afforded them by myo-inositol was not as great as that afforded to E. coli strain B/R organisms.

Table $\mathrm{I}$. The influence of relative humidity on the release of $\left[{ }^{14} \mathrm{C}\right]$ thymidine from Escherichia coli after storage in aerosols for 15 min.

E. coli strain B/R and WP2 $\mathrm{s}$ were held for $15 \mathrm{~min}$. in $\mathrm{N}_{2}$ or air at set values of relative humidity (RH), resuspended in glucose + casamino acids with $(\dagger)$ and without $\left(^{*}\right) 5 \mu \mathrm{g}$. proflavine/ml., incubated at $37^{\circ}$ for $45 \mathrm{~min}$. and the bacteria removed by Millipore filtration. The filtrates were evaporated in vacuo, the solids dissolved in $0.5 \mathrm{ml}$. water, deposited into stainless steel planchettes, dried under an infrared lamp and radioactive counts determined with a gas flow counter. The numbers presented are the radioactive counts $/ \mathrm{min}$. from $10 \mathrm{ml}$. of culture filtrate and are the averages of six independent determinations.

\begin{tabular}{|c|c|c|c|c|c|c|c|c|}
\hline \multirow[b]{2}{*}{ Strain } & \multirow{2}{*}{$\begin{array}{l}\text { Holding } \\
\text { gas }\end{array}$} & \multirow{2}{*}{$\begin{array}{l}\text { Non-dried } \\
\text { control }\end{array}$} & \multicolumn{6}{|c|}{ Holding aerosol relative humidity } \\
\hline & & & 30 & 40 & 50 & 60 & 70 & 80 \\
\hline & & & \multicolumn{6}{|c|}{ radioactivity (counts/min.) } \\
\hline $\mathbf{B} / \mathbf{R}$ & $\begin{array}{l}\text { Air } \\
\mathbf{N}_{2} \\
\mathbf{N}_{2}\end{array}$ & $\begin{array}{l}*_{21} \\
*_{14} \\
+16\end{array}$ & $\begin{array}{r}26 \\
246 \\
44\end{array}$ & $\begin{array}{r}\text { IOI } \\
543 \\
61\end{array}$ & $\begin{array}{r}214 \\
510 \\
66\end{array}$ & $\begin{array}{r}621 \\
640 \\
88\end{array}$ & $\begin{array}{r}533 \\
430 \\
43\end{array}$ & $\begin{array}{r}24 I \\
284 \\
51\end{array}$ \\
\hline WP2 & $\begin{array}{l}\text { Air } \\
\mathbf{N}_{2} \\
\mathbf{N}_{2}\end{array}$ & $\begin{array}{l}{ }^{*} 16 \\
{ }^{*} 14 \\
\dagger_{21}\end{array}$ & $\begin{array}{l}22 \\
42 \\
48\end{array}$ & $\begin{array}{l}19 \\
53 \\
62\end{array}$ & $\begin{array}{l}31 \\
71 \\
59\end{array}$ & $\begin{array}{l}21 \\
92 \\
74\end{array}$ & $\begin{array}{l}33 \\
66 \\
76\end{array}$ & $\begin{array}{l}69 \\
48 \\
52\end{array}$ \\
\hline
\end{tabular}

\section{Effects on respiration}

The rate at which Escherichia coli $\mathbf{B} / \mathrm{R}$ consumed oxygen increased after they had been stored in air or nitrogen at relative humidities between 80 and $55 \%$. At RH values below this, however, storing the organisms in air substantially decreased the respiration rate, but storage in nitrogen did not. $E$. coli $\mathrm{WP} 2_{\mathrm{g}}$, on the other hand, displayed no increase in respiration rate but a decrease, which seemed to parallel the loss in viability (Fig. 4 \& Table 2).

\section{Influence of $N_{2}$ purity}

Throughout these investigations differences seemed to exist between the behaviour of the two strains of Escherichia coli used and that of E. coli $\mathrm{K} \mathrm{I} 2$ as reported by Cox (1968). Both of the strains used here were stable at relative humidities above $80 \%$, which contrasted with the behaviour of the $E$. coli $\mathrm{KI} 2$ strain used by Cox, which apparently is unstable in aerosols at high RH values. The reasons for this discrepancy are not understood, but such effects may result from traces of gaseous toxic materials in the local air emanating from newly painted laboratories, the use of laboratory insecticides, and from the presence of toxic materials in crude nitrogen. Often traces of these toxic materials cause a tendency to high death rates at high relative humidities (Webb, 1965). The effects of using the nitrogen directly from the supply tank and of washing through alkaline pyrogallol only are shown in Fig. 5. When the bacteria were held in aerosols generated with the crude unwashed nitrogen they tended to die more 
rapidly in atmospheres of 70 to $80 \% \mathrm{RH}$. This particular effect was greatly enhanced when the nitrogen was washed through alkaline pyrogallol only; presumably small amounts of pyrogallol in the nitrogen led to the high death rates.

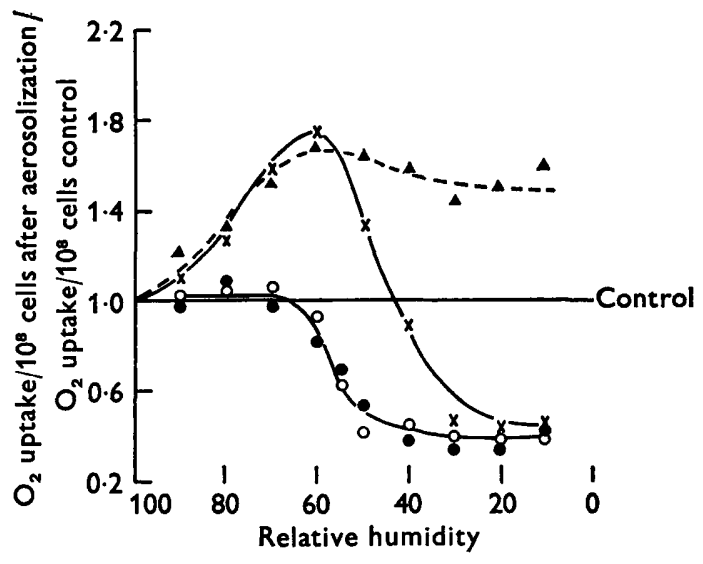

Fig. 4

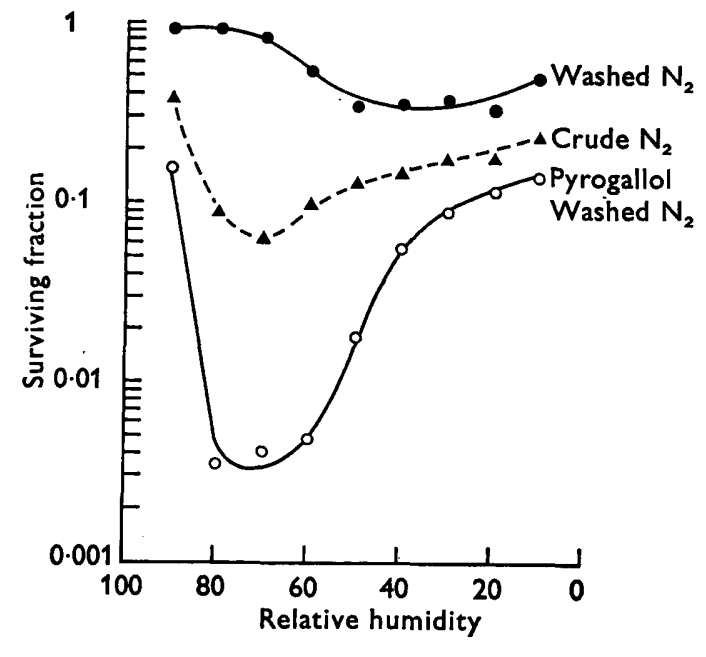

Fig. 5

Fig. 4. The relative rate of glucose oxidation by Escherichia coli strains $B / R$ and $W P 2$ after storage in air or $\mathrm{N}_{2}$ for $15 \mathrm{~min}$. $E$. coli $\mathrm{B} / \mathrm{R}$ in $\mathrm{N}_{2}(\Delta)$, in air $(\times) ; E l$ coli $\mathrm{WP}_{\mathrm{s}}$ in $\mathrm{N}_{2}(\mathrm{O})$, in air (O).

Fig. 5. The effect of the $\mathrm{N}_{2}$ washing procedure on the deaths of $E$. coli $\mathrm{B} / \mathrm{R}$ held for $15 \mathrm{~min}$. in aerosols at various relative humidities.

Table 2. The influence of relative humidity and storage gas on the uptake of $\mathrm{O}_{2}$ by Escherichia coli after $5 \mathrm{~min}$. in aerosols

After aerosolization the bacteria were resuspended in $0 \cdot 1 \mathrm{M}$-potassium phosphate buffer to a total bacterial concentration of $5 \times 10^{8} / \mathrm{ml}$. The number was determined by nephelometry. Triplicate samples of $2 \mathrm{ml}$. were used to measure $\mathrm{O}_{2}$ uptake in a glucose + casamino acids medium (A) and I ml. portions for viable counts on nutrient agar (B). A, $\mathrm{O}_{2}$ uptake $\mu \mathrm{l} . / \mathrm{hr} ; \mathrm{B}, \%$ recovery.

\begin{tabular}{|c|c|c|c|c|c|c|c|c|c|c|c|c|c|c|c|}
\hline \multirow{4}{*}{$\begin{array}{c}\text { Strain } \\
\mathbf{B} / \mathbf{R}\end{array}$} & \multirow{3}{*}{$\begin{array}{c}\text { Storage } \\
\text { gas }\end{array}$} & \multirow{2}{*}{\multicolumn{2}{|c|}{ 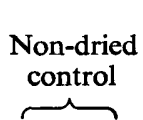 }} & \multicolumn{12}{|c|}{ Holding aerosol relative humidity } \\
\hline & & & & \multicolumn{2}{|c|}{$\overbrace{}^{30}$} & \multicolumn{2}{|c|}{40} & \multicolumn{2}{|c|}{$\underbrace{50}$} & \multicolumn{2}{|c|}{60} & \multicolumn{2}{|c|}{$\overbrace{}^{70}$} & \multicolumn{2}{|c|}{80} \\
\hline & & $\widehat{A}$ & $\underbrace{}_{\mathbf{B}}$ & & $\bar{B}$ & A & $\overline{\mathbf{B}}^{-}$ & $\mathbf{A}$ & $\mathbf{B}$ & A & B & $\mathbf{A}$ & $\mathbf{B}$ & A & B \\
\hline & $\begin{array}{l}\text { Air } \\
N_{2}\end{array}$ & $\begin{array}{l}58 \\
53\end{array}$ & $\begin{array}{l}100 \\
100\end{array}$ & $\begin{array}{l}18 \\
74\end{array}$ & $\begin{array}{l}21 \\
63\end{array}$ & $\begin{array}{l}44 \\
81\end{array}$ & $\begin{array}{l}38 \\
76\end{array}$ & $\begin{array}{l}76 \\
88\end{array}$ & $\begin{array}{l}6 I \\
79\end{array}$ & $\begin{array}{r}104 \\
93\end{array}$ & $\begin{array}{l}8 \mathrm{I} \\
88\end{array}$ & $\begin{array}{l}87 \\
86\end{array}$ & $\begin{array}{l}88 \\
89\end{array}$ & $\begin{array}{l}73 \\
6 r\end{array}$ & $\begin{array}{l}96 \\
94\end{array}$ \\
\hline$W P 2_{\mathrm{S}}$ & $\begin{array}{l}\text { Air } \\
\mathrm{N}_{2}\end{array}$ & $\begin{array}{l}56 \\
54\end{array}$ & $\begin{array}{l}100 \\
100\end{array}$ & $\begin{array}{l}17 \\
16\end{array}$ & $\begin{array}{l}22 \\
30\end{array}$ & $\begin{array}{l}18 \\
17\end{array}$ & $\begin{array}{l}24 \\
35\end{array}$ & $\begin{array}{l}16 \\
24\end{array}$ & $\begin{array}{l}29 \\
40\end{array}$ & $\begin{array}{l}31 \\
36\end{array}$ & $\begin{array}{l}48 \\
59\end{array}$ & $\begin{array}{l}62 \\
59\end{array}$ & $\begin{array}{l}74 \\
68\end{array}$ & $\begin{array}{l}6 I \\
58\end{array}$ & $\begin{array}{l}86 \\
81\end{array}$ \\
\hline
\end{tabular}

\section{DISCUSSION}

It seems clear that the survival of these two strains of Escherichia coli in aerosols of above $50 \% \mathrm{RH}$ is independent of the presence of oxygen. The greater sensitivity of $E$. coli WP2 $2_{\mathrm{s}}$ over $E$. coli $\mathrm{B} / \mathrm{R}$ to semi-dehydration at $\mathrm{RH}$ values above $60 \%$ seems to be due, in part, to an inability of the latter strain to carry out some kind of repair involving the elimination of $260 \mathrm{~m} \mu$.-absorbing material from the cell. $E$. coli $\mathrm{B} / \mathrm{R}$, on the 
other hand, seems capable of overcoming damage produced at high relative humidities by some mechanism which is inhibited by the presence of proflavine in the plating medium. The increased respiration of $E$. coli $\mathbf{B} / \mathbf{R}$ organisms after a period of storage above $60 \%$ RH, a phenomenon which does not occur with $E$. coli WP2, suggests that the mechanism requires energy. Moreover, part of the protective action of both raffinose and myoinositol appears to be to prevent the destruction of this particular mechanism in $E$. coli $\mathrm{B} / \mathrm{R}$ cells. The fact that both the increased respiration and the release of u.v.-absorbing and $\left.{ }^{[14} \mathrm{C}\right]$ thymidine labelled material from the organisms rapidly decreases when they are held in air below $50 \% \mathrm{RH}$ and, at this particular $\mathrm{RH}$ value, oxygen begins to have a lethal action, all suggests that at low $\mathrm{RH}$ values the repairing mechanism is inactivated by oxygen. The ability of raffinose to preserve the integrity of this system when the bacteria are held at low RH values, plus the apparently necessary enhanced respiration, suggests that the mechanism of dehydration repair is controlled by some function of the cytoplasmic membrane.

Bacteria do not possess mitochondria and the mitochondrial function may be exercised by the cytoplasmic membrane. In addition, portions of the bacterial chromosome are known to be in contact with the cytoplasmic membrane at various places. It is possible, therefore, that a compound unable to enter the cell, but able to penetrate partially into the cytoplasmic membrane, would be able to preserve the integrity of that portion of the membrane system involving energy production and the possible repair of those segments of the bacterial chromosome associated with the membrane. The release of u.v.-absorbing materials from organisms held in aerosols at high RH values and those protected by myo-inositol at low $\mathrm{RH}$ values has been reported earlier (Webb, 1965). The liberation of this material from the bacteria has been found to be associated with survival rather than with death. To the author's knowledge, however, this release of material has not been suggested to be characteristic of particular strains. The nature of this repair system remains to be elucidated, but it is possibly the same mechanism as that responsible for the 'dark' repair by u.v.-induced damage. Because oxygen seems to be required to inactivate the system, some easily oxidizable cellular constituent appears to be involved in the repair mechanism. These types of compound are involved also in the respiratory systems of the organism which seem to be stimulated during the process of repair. Such considerations, along with the diminished respiration of the organisms after storage in air of low relative humidities, points to death resulting from the inactivation at low $\mathrm{RH}$ values of some part of the mitochondrial or cytochrome system which, in some strains, is able to repair semi-dehydration damage. The apparent action of oxygen on this repair mechanism may also explain why oxygen seems to play no role in the inactivation of airborne viruses (deJong \& Winkler, I968). Certain experimental procedures, such as the exposure of bacteria to $365 \mathrm{~m} \mu$. light (Kelner, 1949), holding them in water or at elevated temperatures (Stein \& Meutzner, 1950) will induce some cells to repair u.v. damage of DNA. Whether or not these procedures stimulate the operation of parts of a single metabolic process is uncertain; however, all of them, including the 'dark' repair of u.v. or semi-dehydration damage, seem to rely on an enhanced activity of the cytochrome chain produced either by an increase in respiration rate or the absorption of $365 \mathrm{~m} \mu$. light by the quinones or flavenoid pigments of this chain. The finding that some bacteria possess a system by which they are able to overcome semi-dehydration damage presents the interesting possibility that those repair systems able to cope with damage due to $254 \mathrm{~m} \mu$. u.v. 
radiation, a wavelength not present in sunlight, may have evolved in response to other physical stresses such as semi-dehydration and extremes of temperature. Indeed, in some cases, these systems now may have evolved to a point where the continuity of biological life cycles, especially the germination of spores or seeds, depends on the activation of the system through exposure to periods of semi-dehydration, extremes of temperature and even sunlight itself (Borthwick et al. 1952).

The apparent difference between the behaviour at $80 \% \mathrm{RH}$ of the two strains of Escherichia coli used here and that used by Cox (1968) may be due to the condition of the air existing in respective laboratories or the purity of the nitrogen used. Alternatively, the strain used by Cox may lack a repair system or its prophage may be a defective one. The latter is suggested since semi-dehydration at $\mathrm{RH}$ values above $70 \%$ will induce some prophages and, should the prophage be a defective one or made defective by the dehydration process, simple plaque counts would not detect induction (Webb \& Dumasia, 1967a, $b$ ).

The author thanks the Defence Research Board of Canada for its financial support of this work.

\section{REFERENCES}

Ashwood-SmIth, M. J. \& BRIDGes, B. A. (1966). Ultraviolet mutagenesis in Escherichia coli at low temperatures. Mutation Res. 3, 135.

Borthwick, H. A., Henricks, S. B., Parker, M. W., Tooke, E. H. \& ToOle, V. (I952). Reversible photoreaction controlling seed germination. Proc. natn. Acad. Sci. U.S.A. 38, 662.

Cox, C. S. (1967). The aerosol survival of Escherichia coli JEPP sprayed from protecting agents into nitrogen atmospheres under changing conditions of relative humidity. J. gen. Microbiol. 49, 109.

Cox, C. S. (1968). The aerosol survival and cause of death of Escherichia coli x I2. J. gen. Microbiol. 54, 169.

DEJoNG, J. C. \& WinkLER, K. C. (1968). The inactivation of poliovirus in aerosols. J. Hyg., Camb. 66, 557.

Hess, G. C. (1965). Effects of oxygen on aerosolized Serratia marcescens. Appl. Microbiol. 13, 78I.

HILL, R. F. (1965). Ultraviolet-induced lethality and reversion to prototrophy in Escherichia coli strains with normal and reduced dark repair ability. Photochem. Photobiol. 4, 563.

KELNER, A. (1949). Photoreactivation of ultraviolet irradiated $E$. coli with special reference to the dose reduction principle and to ultraviolet induced mutation. J. Bact. 58, 5 I I.

LIEB, M. (1964). Dark repair of u.v. induction in $\mathrm{K} 12(\lambda)$. Virology 23, $38 \mathrm{I}$.

STEIN, W. \& MEUTZNER, I. (1950). Reaktivierung von UV-inaktivierten Bakterium coli durch warme. Naturwissenschaften 37, 169.

WEBB, S. J. (1960). Factors affecting the viability of air-borne bacteria. III. The role of bonded water and protein structure in the death of air-borne cells. Can. J. Microbiol. 6, 89.

WeBB, S.J. (1965). Bound Water in Biological Integrity. Springfield, Illinois, U.S.A.: Charles C. Thomas.

WEBB, S. J. (1967). The influence of oxygen and inositol on the survival of semidried microorganisms. Can. J. Microbiol. 13, 733.

WebB, S. J. \& Dumasia, M. D. (1967a). The induction of lambda prophages by controlled desiccation. Can. J. Microbiol. 13, 33.

WebB, S. J. \& DumasiA, M. D. (1967b). Bound water, inositol and the induction of lambda prophages by ultraviolet light. Can. J. Microbiol. 13, 303.

WeBB, S. J. \& TAI, C. C. (1968). Lethal and mutagenic action of 3200-4000 §̊ light. Can. J. Microbiol. I4, 727.

Wells, W. F. (1955) Air Hygiene and Air Contagion. Boston, Massachusetts: Harvard University Press.

WrTKIN, E. M. (1963). The effect of acriflavin on photoreversal of lethal and mutagenic damage produced in bacteria by ultraviolet light. Proc. natn. Acad. Sci. U.S.A. 5o, 425. 